Katarzyna Skotnicka

\title{
Antoni Pustelnik W ŚWietle relacji HISTORYKÓW KOŚCIELNYCH V WIEKU
}

Anachoretyzm egipski odgrywał w dziejach monastycyzmu niezwykle ważną rolę, choć obecny stan wiedzy nie pozwala jednoznacznie stwierdzić, że był on pierwszym tego rodzaju ruchem w świecie chrześcijańskim. Mnisi egipscy stali się wzorami dla swoich odpowiedników z innych części chrześcijańskiego świata. Chcąc podnieść własne znaczenie, wiele wspólnot monastycznych szukało swoich korzeni w środowisku mnichów egipskich ${ }^{1}$. W pierwszych wiekach istnienia ruchu monastycznego takie powiązania wcale nie były oczywiste, podobnie w oczach historyków kościelnych kwestia powstania monastycyzmu wcale nie łączyła się tak silnie z Egiptem. Wyraz temu daje Sozomen, który wprost stwierdził, że „nie wiadomo, czy to Egipcjanie, czy też jacyś inni wyznawcy zapoczątkowali tę filozofię"”. Niemniej według Sozomena wszyscy są zgodni, że ten sposób życia do doskonałości doprowadził egipski mnich Antoni ${ }^{3}$, żyjący na przełomie III i IV wieku. W jaki zatem sposób historycy, opisujący dzieje Kościoła w następnym stuleciu, postrzegali tę postać? Co wiedzieli na temat jego życia i skąd czerpali informacje na jego temat? Na te pytania postaram się odpowiedzieć w niniejszym artykule.

Spośród Historii Kościoła trzy wspominają o Antonim Pustelniku. Najmniej miejsca postaci tej poświęca Teodoret, co jest całkowicie zrozumiałe, jeśli weźmie się pod uwagę inny geograficzny rejon, którym zainteresowany był biskup Cyru. Bardzo dużo miejsca poświęca za to Antoniemu Sozomen. Wiele informacji znajdziemy również u Sokratesa. Informacje podane przez Historie Kościoła

\footnotetext{
${ }^{1}$ Przykładem może tu być mezopotamska legenda o Mar Auginie, która wskazywała na taką właśnie zależność. Obecnie wiadomo jednak, że wpływ Egiptu na monastycyzm mezopotamski, jeśli istniał, to rozpoczął się najwcześniej $\mathrm{w} \mathrm{V}$ w. n.e., a do tej pory asceza w tym kraju miała charakter miejscowy. Legenda, o której wspomniałam, pochodzi dopiero z IX wieku. Zob. W. Harmless, Chrześcijanie pustyni. Wprowadzenie do literatury wczesnego monastycyzmu, tłum. M. Hoffner, Kraków 2009, s. 496.

${ }^{2}$ Sozomen, Historia Kościoła I 13, tłum. S. Kazıкowski, Warszawa 1980, s. 57 (dalej: Sozomen, $H E)$.

${ }^{3}$ Sozomen, HE I 13.
} 
skonfrontować można z innymi źródłami. Wiele o Antonim powiedzą nam Historia Mnichów w Egipcie oraz Opowiadania dla Lausosa; dużo miejsca poświęcają temu mnichowi Apoftegmaty. Najważniejszym źródłem do badania dziejów Antoniego Pustelnika jest oczywiście jego żywot napisany przez Atanazego. Dysponujemy również listami ascety. Znana jest także reguła zakonna, ale nie ma wątpliwości, że to nie Antoni jest jej autorem.

Sokrates opisując Antoniego powołuje się na dzieło Atanazego:

Jakimi cechami charakteru wyróżniał się w tych samych czasach w egipskiej pustelni mnich Antoni, który podejmował otwartą walkę ze złymi duchami, w prosty sposób demaskując ich sztuczki i chwyty, i jak wielu dokonał cudów, nie potrzebuję na ten temat mówić. Uprzedził mnie w tym Atanazy, biskup Aleksandrii, publikując księgę poświęconą jego życiu

Po raz kolejny Sokrates wspomina o Antonim opisując mnicha Ammona. Relacja ta jest równie krótka, co pierwsza, i ponownie zawiera odwołanie do dzieła Atanazego:

Współczesny Ammonowi Antoni - jak to opowiada w jego żywocie biskup Aleksandrii, Atanazy - widział, jak po śmierci pustelnika aniołowie unosili jego duszę do nieba ${ }^{5}$.

Sozomen i Teodoret, opisując Antoniego, nie odwołują się bezpośrednio do dzieła Atanazego, ale z całą pewnością znali twórczość biskupa Aleksandrii. Sokrates znał też twórczość Palladiusza i Historię mnichów w Egipcie. Jeśli chodzi o Sozomena, to pewne jest, iż znał on tę drugą pozycję; co do Opowiadań dla Lausosa można mieć pewne wątpliwości.

Spośród historyków Kościoła najwięcej informacji biograficznych dotyczących Antoniego przekazuje Sozomen. Nie podaje on, w jakich latach żył Antoni Wielki, ale z innych relacji wiadomo, że chodzi o lata ok. 251-356 . Pustelnik urodził się w Egipcie, w mieście Koma ${ }^{7}$. Nazwę tego miejsca wspomina Sozomen:

Antoni był rodem z Egiptu i wywodził się ze znamienitej rodziny, osiadłej w Koma.

Miejscowość ta leży w pobliżu Heraklei, na terytorium zamieszkałym przez egipskich Arkadów ${ }^{8}$.

W Egipcie znajdowały się dwa miasta o nazwie Herakleja: Herakleja Większa i Mniejsza. Dokładną identyfikację ułatwia wzmianka o egipskich Arkadach - na tej podstawie stwierdzić można, że chodzi tu o Herakleję Mniejszą, znajdu-

\footnotetext{
${ }^{4}$ Sokrates, Historia Kościoła I 21, tłum. S. Kazikowski, Warszawa 1972, s. 75 (dalej: Sokrates, HE).

${ }^{5}$ SOKRATES, HE IV 23.

${ }^{6}$ E. Wipszycka, Wprowadzenie, [w:] Święty Antoni. Żywot. Pisma ascetyczne, tłum. E. DĄвrowska, A. ZióŁkowski, M. Borkowska, S. Kazikowski, S. Kalinkowski, Z. Brzostowska, Kraków 2005, s. 13.

${ }^{7}$ M. Kanion, Historia monastycyzmu chrześcijańskiego, Kraków 1993, s. 35.

${ }^{8}$ Sozomen, HE I, 13.
} 
jącą się w Dolnym Egipcie ${ }^{9}$. Dzisiaj miejscowość ta nazywa się Qiman al Arus ${ }^{10}$. Co ciekawe, nazwy tej miejscowości nie przekazuje w swoim dziele Atanazy, który informuje jedynie, że Antoni pochodził z Egiptu ${ }^{11}$, widać więc wyraźnie, że Sozomen musiał korzystać z jakiejś późniejszej tradycji. Nazwy tej miejscowości nie znajdziemy również w żadnym innym źródle.

Zgodnie z relacją Atanazego, po śmierci rodziców Antoni sprzedał majątek i rozpoczął życie ascety. Sumę, którą uzyskał w wyniku sprzedaży, rozdzielił pomiędzy potrzebujących ${ }^{12}$. Część pieniędzy przeznaczył na utrzymanie swojej siostry, którą umieścił w domu miejscowych dziewic ${ }^{13}$. O wydarzeniu tym Atanazy wspomina następująco:

Wyszedłszy więc natychmiast z Domu Pańskiego, całą posiadłość, którą miał po przodkach [...], oddał chłopom ze swej wsi, aby ani jemu, ani siostrze nie sprawiano kłopotu; sprzedał wszystkie ruchomości, a uzyskane pieniądze dał biednym, zostawiając małą sumkę dla siostry ${ }^{14}$.

Odpowiedni fragment odnoszący się do wyzbycia się rodzinnego majątku przez Antoniego znajdziemy także w relacji Sozomena. Nie wspomina on jednak o losach siostry pustelnika, wyjaśnia natomiast powody podjęcia przez niego takiego kroku:

[...] uznał bowiem [Antoni], że obowiązkiem gorliwego filozofa jest nie tylko samemu wyzbyć się majątku, lecz także poświęcić go na cel godziwy ${ }^{15}$.

Rozdanie majątku jest częstym epizodem w opowiadaniach o chrześcijańskich mnichach. Sozomen nie wyjaśnia, jakie były przyczyny wyboru pustelniczego życia przez Antoniego, takie informacje znajdziemy za to u Atanazego ${ }^{16}$.

Niestety brak u Sozomena wielu szczegółów dotyczących dalszego życia Antoniego. Wspomina on jedynie, że po rozdaniu swojego majątku Antoni „przyłączywszy się do współczesnych mistrzów ascezy starał się wszystkich przewyższyć w cnotach"17. Z relacji Atanazego wiemy, iż kilkanaście lat Antoni spędził $\mathrm{w}$ rodzinnym mieście, a następnie zamieszkał w starożytnym grobowcu $\mathrm{z}$ dala od niego. Przybywali tam ludzie pragnący naśladować jego sposób życia. Antoni

\footnotetext{
${ }^{9}$ Zob. przypis $35 \mathrm{w}$ : Sozomen, HE I, 13.

${ }^{10}$ H. Dyвsкi, Początki anachoretyzmu w Egipcie w świetle nauczania Ojców Kościoła IV I V wieku, „Studia Teologiczne” 27 (2009), s. 213.

${ }^{11}$ Atanazy, Żywot św. Antoniego, tłum. E. Dąвrowska, A. Zıó Kowski, S. Kalinkowski, Z. Brzostowska, Kraków 2005, s. 9 (dalej: Atanazy, VA).

12 Sozomen, HE I, 13.

${ }_{13}$ Atanazy, VA 2, 3-5.

${ }^{14}$ Ibidem.

${ }^{15}$ Sozomen, HE I, 13.

${ }^{16}$ Atanazy, VA 2. Antoni miał usłyszeć fragment Pisma Świętego, mówiący o konieczności wyzbycia się majątku (Mt 19,21), i pod jego wpływem rozpoczął życie pustelnika.

${ }^{17}$ Sozomen, HE I, 13.
} 
uznał, że taka sytuacja nie odpowiada jego potrzebom, i w roku 286 udał się do niewielkiej opuszczonej fortecy. Jednak również tam odnaleźli go jego naśladowcy. Zamieszkali w pobliżu mistrza i w ten sposób utworzyli jedno z pierwszych skupisk anachoreckich, które nosiło nazwę Pispir. Było to około roku 305. Dokładna lokalizacja tego miejsca nie jest pewna, najprawdopodobniej były to okolice miasta Afroditopolis ${ }^{18}$. Zgodnie z relacją Atanazego „powstały i w górach pustelnie, i pustynia stała się miastem mnichów [... "19. Wszystkich mieszkających tam ascetów łączył autorytet pustelnika. Choć nie posiadał on formalnego stanowiska wśród tej społeczności, traktowano Antoniego jako arbitra i wzór do naśladowania ${ }^{20}$. Tłumy napływające stale do pustelnika wymusiły na nim kolejne przenosiny. Poprosił on koczowniczych Arabów, podróżujących po skalnych pustyniach, żeby go ze sobą zabrali ${ }^{21}$. Około roku 312 zatrzymał się w oazie u podnóża góry Qolzum.

Choć Sozomen pominął wiele ważnych epizodów z życia pustelnika, przekazał cenne informacje dotyczące jego życia codziennego. Znajdują się wśród nich fakty dotyczące pożywienia, nocnych czuwań i modlitwy, snu, higieny osobistej i podejścia do pracy. Zgodnie z relacją Sozomena Antoni rozważał wszechstronnie sposoby surowej ascezy, popędy cielesne natomiast poskramiał umartwianiem $s_{i e ̨} e^{22}$. Jednym z podstawowych elementów ascezy jest post. Atanazy podaje, że Antoni wstydził się swojej potrzeby jedzenia, często wymawiał się od jedzenia razem z innymi mnichami, ponieważ uważał, że się czerwieni, kiedy inni widzą go przy jedzeniu $^{23}$. Post Antoniego, zdaniem Sozomena, polegać miał na spożywaniu jedynie chleba z solą i piciu wody. Posiłek taki miał miejsce w momencie zachodu słońca. Zdarzało się jednak, że Antoni wytrzymywał bez jedzenia dwa dni lub nawet więcej ${ }^{24}$. Atanazy nie podaje, przez jak wiele dni Antoni potrafił pościć, nie znajdziemy również tej informacji w Historii mnichów w Egipcie ani u Palladiusza. Pozostaje więc uznać, że informacja o dłuższych postach Antoniego pochodzi z innego źródła (być może została przekazana ustnie). Odniesienie do pory spożywania posiłków znajdziemy natomiast w Historii Mnichów w Egipcie. Zgodnie z jej relacją Antoni nakazał Pawłowi Pustelnikowi:

\footnotetext{
${ }_{18} \mathrm{~W}$ ten sposób powstało pierwsze $\mathrm{w}$ dziejach chrześcijaństwa skupisko mnichów o charakterystycznej strukturze. Tworzyli je pustelnicy żyjący osobno w swoich celach, każdy z nich miał własne zasady, tryb życia i uprawiania ascezy. Wszyscy jednak uznawali moralny autorytet Antoniego, zob. J. Danielou, H. I. Marrou, Historia Kościoła. Od początków do roku 600, tłum. M. Tarnowska, Warszawa 1986, s. 213.

19 Atanazy, VA 13.

${ }^{20}$ M. Kumor, Historia monastycyzmu chrześcijańskiego, t. 1, Kraków 1993, s. 37.

${ }^{21}$ E. Wipszycka, Święty Antoni, czyli o pierwszych pustelnikach, [w:] O starożytności polemicznie, Warszawa 1994, s. 199.

22 Sozomen, HE I 13

${ }^{23}$ Atanazy, VA 45.

${ }^{24}$ Sozomen, HE I 13.
} 
[...] jeść wieczorem, ale pilnować, by nigdy nie doszedł do sytości, szczególnie w piciu. Twierdził bowiem, że jak przez wino wzrasta ciepłota ciała, tak przez nadmiar wody pojawiają się zwidy ducha ${ }^{25}$.

Relacja z Historii Mnichów zgadza się więc z tym, co napisał Sozomen. Podstawę wyżywienia Antoniego, zgodnie z relacją Sozomena, stanowił chleb z solą. Chleb generalnie był najczęściej spożywanym na pustyni produktem ${ }^{26}$. Choć Sozomen nie podaje, jak wyglądał chleb jedzony przez Antoniego, wiadomo, że asceci egipscy jedli chleb, który wielkością przypominał dzisiejszą bułkę, był więc mały i okrągły ${ }^{27}$. Mnisi stosowali nieoczyszczoną i grubo zmieloną mąkę. Chleb wypiekany był jedynie kilka razy do roku, dlatego często wspomina się o konieczności moczenia bochenka w wodzie przed zjedzeniem. W innym wypadku pieczywo nie nadawałoby się do spożycia. Wysuszony tuż po wypieczeniu chleb miał jednak jedną ważną dla mnichów zaletę - można go było przechowywać przez bardzo długi czas bez obaw, że się zepsuje. Dlatego też wysuszone bochenki były podstawowym pożywieniem zabieranym w podróż. Sozomen nie wspomina, by Antoni moczył chleb przed jedzeniem, ale robi to Palladiusz ${ }^{28}$. Sozomen nie informuje, skąd Antoni brał chleb. Atanazy natomiast sugeruje, że Antoni zarabiał na niego pracą ręczną ${ }^{29}$.

W życiorysie św. Antoniego uwagę przykuwa jego potrzeba ciągłej ucieczki od ludzi, w chęci osiągnięcia spokoju, który dałby mu możliwość praktykowania ascezy $^{30}$. Nie można jednak powiedzieć, że całe swoje życie Antoni spędził w izolacji od świata zewnętrznego. Były okresy, w których opuszczał swoją pustelnię a nawet mieszał się w sprawy społeczeństwa. Do przedstawienia działalności Antoniego wśród mieszkańców Aleksandrii bardzo pomocna będzie Historia Kościoła Sozomena. Zgodnie z jego relacją:

\footnotetext{
${ }^{25}$ Historia Mnichów w Egipcie, tłum. E. DĄBrowska, Kraków 2007, s. 265 (dalej: HM).

${ }^{26}$ Wspomina o nim Ewagriusz z Pontu w swoim dziele poświęconym ascezie, radząc mnichom, aby, gdy czują potrzebę urozmaicenia pokarmów, ograniczali się do chleba i wody. Święty Pachomiusz w swojej Regule opisuje nawet pracę piekarzy i wydaje im zalecenia. Również w Apoftegmatach można znaleźć opisy mnichów żywiących się chlebem. Przykładowo Abba Achillas spożywał posolony chleb, zmiękczony wodą. Chleb stanowił główne pożywienie także dla mnichów zamieszkujący Pustynię Judzką. Wspomina go także wielokrotnie Teodoret z Cyru w dziele Historia religiosa, jako podstawę wyżywienia mnichów syryjskich. Zob. Ewagriusz z Pontu, O praktyce [ascetycznej], 16; św. Pachomiusz, Reguly 116-117, [w:] Pachomiana Latina, tłum. A. Bober, W. Miliszkiewicz, M. Starowieyski, Kraków 1996, s. 150-151; Apoftegmat 3, [w:] Apoftegmaty Ojców Pustyni, tłum. M. BorkowsKa, t. 1: Gerontikon, Kraków 2007, s. 126 (dalej: AP).

${ }^{27}$ E. WipszycKa, Mnisi - nie tylko ci święci..., Kraków 2007, s. 56.

${ }_{28}$ Palladiusz, Opowiadania dla Lausosa, tłum. S. Kalinkowski, Kraków 1996, s. 137 (dalej: HL).

29 Atanazy, VA 3.

${ }^{30}$ Postępowanie takie określano mianem kseniteja, czyli 'wygnanie', a powtarzane być powinno za każdym razem, gdy mnich przestaje być obcy w miejscu, w którym przebywa. Idea ta doprowadziła do powstania monastycyzmu wędrownego, szczególnie popularnego w Mezopotamii i Syrii (zob. A. Guillaumont, U źródeł monastycyzmu chrześcijańskiego, tłum. S. Wirpszanka, t. 1, Kraków 2006, s.143).
} 
[...] jeśli chodziło o wstawianie się za pokrzywdzonymi, był tak niesłychanie gorliwy, jak mało kto inny; toteż w sprawach tych niejednokrotnie udawał się do różnych miast. Wielu bowiem przedkładając mu swe żale zmuszało go, by się wstawił $\mathrm{w}$ ich obronie u władz i urzędników, jako że każdy za wielką rzecz uważał bodaj ujrzeć go i posłuchać, jak przemawia, a wreszcie okazać mu posłuszeństwo jakby przełożone$\mathrm{mu}[\ldots]^{31}$.

Sozomen mówi wyraźnie, że liczba osób zwracających się z prośbą o wstawiennictwo było duża. Fakt ten podkreśla po raz drugi, relacjonując wizytę Hilariona u św. Antoniego. Zgodnie z relacją historyka Hilarion:

[...] udał się na pustynię powodowany chęcią odwiedzenia wielkiego mnicha-pustelnika, i po rozmowie z nim postanowił, że tak samo będzie prowadził życie oddane chrześcijańskiej mądrości. Zabawiwszy tam czas jakiś niedługi, powrócił do ojczyzny: nie mógł bowiem przebywać w pustelni tak długo, jak tylko by chciał, bo tych, co przychodzili do Antoniego, było przy każdej sposobności niemało ${ }^{32}$.

W przeciwieństwie do ludzi opisywanych we wcześniejszym cytacie Hilarion nie przybył do Antoniego z prośbą o wstawiennictwo, ale udał się do niego jak do nauczyciela, by obserwować jego ascezę. Fakt, że pustelnik był proszony o wstawiennictwo, nie jest niczym dziwnym ${ }^{33}$.

Sozomen dwukrotnie informuje o wymianie listów pomiędzy Antonim i władcami Bizancjum. Pierwsza wzmianka jest dość krótka: cesarz Konstantyn uczynił ascetę swoim przyjacielem, zaszczycił go listem i polecił pisać o wszystkim, czego potrzebuje $\mathrm{e}^{34}$. Opis ten zgadza się z tym, co przekazał Atanazy: wieść o Antonim miała dotrzeć do władców, którzy napisali do niego jak do ojca, prosząc o odpowied $z^{35}$. Atanazy podaje jednak ważną wskazówkę chronologiczną - mowa jest bowiem nie o samym Konstantynie, ale także o jego dwóch synach Konstancjuszu i Konstansie, którzy w momencie pisania listu byli już cezarami ${ }^{36}$. List ten musiał być więc napisany po uzyskaniu tego tytułu przez obu braci, a przed śmiercią Konstantyna, czyli w latach 333-337. Ciekawa relacja na temat korespondencji cesarza z mnichem znajduje się także w Apoftegmatach: Antoni miał dostać list wzywający go do Konstantynopola ${ }^{37}$.

${ }^{31}$ Sozomen, HE I, 13.

32 Sozomen, HE III, 14.

${ }^{33}$ Podobne opowieści bardzo często pojawiają się w źródłach monastycznych i mają dwa główne cele: $\mathrm{z}$ jednej strony pokazują wspaniałomyślność pustelnika, który dla obrony pokrzywdzonych jest w stanie ponieść każdy trud, z drugiej natomiast podkreślają wielki autorytet mnicha, który posiadał wpływ na decyzje podejmowane przez urzędników czy nawet władców.

${ }^{34}$ Sozomen, HE I, 13

${ }^{35}$ Atanazy, VA 81

${ }^{36}$ Ibidem.

37 Apoftegmat 31, AP, s. 145: „Nie wiedząc, co zrobić, zapytał o radę swojego ucznia - Pawła Prostaka, który stwierdził, że jeśli Antoni pojedzie, będzie nazywany Antonim, ale jeśli zdecyduje się nie pojechać, zostanie nazwany abba Antoni”. 
Problem pojawia się, gdy weźmiemy pod uwagę drugą relację Sozomena o wymianie listów między cesarzem a Antonim. Korespondencja ta dotyczyć miała osoby Atanazego - pustelnik wstawiał się za zesłanym na wygnanie biskupem. List ten miał zostać wysłany już po śmierci Ariusza, a więc po roku 336, ale przed śmiercią Konstantyna, czyli przed 337 rokiem. Ewa Wipszycka we wstępie do Żywota sugeruje, powołując się na opinię K. Heussi ${ }^{38}$, że przekazy te dotyczą tej samej wymiany listów ${ }^{39}$. Trudno nie zgodzić się z takim rozumowaniem. W tak wczesnej epoce chrześcijaństwa byłoby zadziwiające, gdyby cesarz sam wyszedł z inicjatywą napisania listu do ascety ${ }^{40}$. Dzieło, które wyniosło sławę Antoniego poza Egipt, czyli Żywot napisany przez Atanazego, powstało około dwudziestu lat po wspomnianej wymianie korespondencji. Jest więc bardzo możliwe, że cesarz mógł nawet nie słyszeć o Antonim. Dlatego uważam, że możliwość rozpoczęcia tej wymiany listów przez cesarza należy odrzucić. Istnieje jednak druga wersja tej historii: to Antoni jako pierwszy napisał list do cesarza, z prośbą o przywrócenie Atanazego na tron biskupi, a cesarz udzielił mu odpowiedzi. Zgodnie $\mathrm{z}$ tą teorią pierwszym chronologicznie listem byłby ten, który Sozomen opisuje w drugiej kolejności. Jeśli przyjąć tu datację zasugerowaną przez Atanazego, to zarówno list Atanazego, jak odpowiedź cesarza musiałyby być wysłane w latach 333-337. Jeśli jednak odniesiemy się do relacji Sozomena, to list Antoniego i odpowiedź udzielona przez Konstantyna musiałyby mieć miejsce pomiędzy śmiercią Ariusza a śmiercią Konstantyna, czyli między 336 a 337 rokiem.

Rozbieżności pomiędzy tym, co napisał Sozomen, a relacją pozostałych źródeł czy opinią współczesnych historyków, nie dotyczą tylko czasu wysłania listów czy ich liczby, ale także ich zawartości. Istnieje bowiem sprzeczność pomiędzy relacją Atanazego a Sozomena. Jeśli uznamy, że nasze wcześniejsze ustalenia są prawdziwe i istniała tylko jedna wymiana listów, musimy ustalić, który z dwóch autorów - Sozomen czy Atanazy - podawał prawdziwą treść listu cesarza. Atanazy nie przekazuje zbyt wielu szczegółów, twierdzi jedynie, że władcy napisali do Antoniego jak do ojca i prosili o odpowiedź. Zgadzałoby się to z tym, co napisał Sozomen, kiedy pierwszy raz wspomniał o wymianie korespondencji, ale całkowicie kłóci się z jego drugą wzmianką o listach. Oczywiście najłatwiej byłoby w tym miejscu przyznać, że doszło do aż dwukrotnej wymiany listów pomiędzy cesarzem a Antonim, ale to, jak wyjaśniliśmy wyżej, jest mało możliwe. W drugiej relacji o listach Sozomen dokładnie przytacza odpowiedź cesarza:

Odpowiadając zaś Antoniemu dał do zrozumienia, że on, cesarz, nie może sobie lek-
ceważyć orzeczenia synodu. Bo jeżeli nawet ci i owi - pisał do niego - rozsądzając
sprawę kierowali się niechęcią czy sympatią, to przecież wprost nie do pomyślenia,
aby tego rodzaju nastawienie miała olbrzymia rzesza wykształconych i pobożnych
biskupów. Bo, co dotyczy Atanazego, jest on pyszałkiem i człowiekiem, który nie
przebiera w słowach, i to on ponosi winę za niezgodę i niepokój $j^{41}$.

${ }^{38}$ K. Heussi, Der Ursprungdes Monchtums, Tübingen 1936, s. 86.

39 E. Wipszycka, Wstęp, s. 39, [w:] Atanazy, VA.

${ }^{40}$ Ibidem, s. 40.

${ }^{41}$ Sozomen, HE II, 31. 
Z dużą dozą pewności można w tej kwestii stwierdzić, że relacja Sozomena jest tą bliższą prawdy. Jest ona zgodna z tym, co wiemy o polityce Konstantyna względem Atanazego. Poza tym historia ta jest o tyle prawdopodobna, że zarówno cesarza, jak i mnicha stawia w niezbyt korzystnym świetle, Antoni bowiem nie uzyskał tego, co chciał, a cesarz odmówił osobie uznawanej za świętą. Kolejnym argumentem przemawiającym za tym, że to relację Sozomena należy uznać w tym wypadku za prawdziwą, jest fakt, że druga $\mathrm{z}$ informacji pochodzi od samego Atanazego. Trudno się dziwić, że ten ostatni nie przekazał odpowiedzi, w której cesarz określa go jako pyszałka, który ponosi winę za niezgodę i niepokój.

Na podstawie Historii Kościoła przedstawić można również relację na linii Antoni-Atanazy ${ }^{42}$. Z dzieła Sozomena wywnioskować można, że znajomość Atanazego z Antonim rozpoczęła się jeszcze przed wyborem tego pierwszego na biskupa. Sozomen pisze bowiem, że kiedy po śmierci Aleksandra biskupem został Atanazy, jego sława wzrosła umacniana m.in. „świadectwem wielkiego mnicha Antoniego" ${ }^{43}$. Wynika z tego, że poznali się oni jeszcze przed rokiem 328. Sam Atanazy we wstępie do Żywota św. Antoniego informuje, że widywał go często, nie wiemy jednak, co dokładnie to określenie oznacza ${ }^{44}$. Najprawdopodobniej Atanazy poznał mnicha, kiedy w okresie swojej młodości przebywał na pustyni.

${ }^{42}$ Istnieje bardzo wiele prac poświęconych Atanazemu: D. W.-H. Arnold, The Early Episcopal Career of Athanasius of Alexandria, "Christianity and Judaism in Antiquity” 6 (1991), Notre Dame; D. Brakke, Athanasius, [w:] The Early Christian World, ed. P. F. Esler, t. 2, New York 2000, s. 11021127; T. D. BARnes, Athanasius and Constantius: Theology and Politics in the Constantinian Empire, Cambridge, Mass. 1993; D. Brakke, Athanasius and Asceticism, Baltimore 1998; T. G. Elliott, The Christianity of Constantine the Great, Scranton 1996, s. 371-320; W. H. C. Frend, Athanasius as an Egyptian Christian Leader in the Fourth Century, [w:] Religion Popular and Unpopular in the Early Christian Centuries, XVI, London 1976, s. 20-37; R. P. C. Hanson, The Search for the Christian Doctrine of God: The Arian Controversy, 318-381 AD, Edinburgh 1988, s. 239-273; Ch. KANNENGIEsser, Athanasius of Alexandria and the Ascetic Movement of His Time, [w:] Asceticism, ed. V. Wimbush, R. Valantasis, New York 1995, s. 479-492; K. Anatolios, Athanasius: The Coherence of His Thought, New York 1998. A. Louth, Athanasius' Understanding of the Humanity of Christ, „Studia Patristica” 16 (1985), s. 309-323. Ch. KANnENGIEsser, Athanasius of Alexandria and the Foundation of Traditional Christology, „Theological Studies” 34 (1973), s. 103-113; R. J. Lyman, Christology and Cosmology: Models of Divine Activity in Origen, Eusebius, and Athanasius, New York 1993; E. P. MeIjering, Athanasius on the Father as the Origin of the Son, [w:] God Being History: Studies in Patristic Philosophy, Amsterdam 1975; A. Pettersen, Athanasius, Harrisburg 1995.

Z polskich opracowań wymienić można: P. M. SzewCZYK, Atanazy z Aleksandrii, biskup i mnich, „Vox Patrum”, R. 28, t. 52 (2008), cz. 2, s. 1085-1094; S. Longosz. Święty Atanazy Aleksandryjski a Biskup Rzymu, „Vox Patrum”, R. 24, t. 46/47 (2004), s. 163-191; P. JURzyк, Wybrane elementy napastliwej polemiki antyariańskiej w „Orationes contra Arianos” św. Atanazego Wielkiego na tle literackiej tradycji inwektywy, „Wrocławski Przegląd Teologiczny”, R. 14, 2 (2006), s. 179-195.

${ }^{43}$ Sozomen, HE II, 17.

${ }^{44}$ E. Wipszycka, Wstęp, s. 31, [w:] Atanazy, VA. 
Wiemy, także z relacji historyków kościelnych, że Antoni stał po stronie Atanazego $\mathrm{w}$ jego sporach $\mathrm{z}$ arianami. Spośród trzech historyków wspominających tego mnicha nie informuje o tym jedynie Sokrates. Teodoret z Cyru ogranicza się do krótkiego wspomnienia o tym, że takie wstawiennictwo miało miejsce. Zgodnie z jego relacją Antoni opuszczał pustynię i udawał się do Aleksandrii, aby zaświadczać o prawowierności Atanazego, a arian nazywać wrogami prawdy ${ }^{45}$. Podobnie Sozomen zaświadcza, że Antoni przybywał do Aleksandrii na każde wezwanie biskupa oraz wyrażał swą zgodę na wszystkie jego poglądy dotyczące Bóstwa, a poza tym okazywał mu zawsze swą przyjaźń i unikał jego przeciwników czy zdecydowanych wrogów ${ }^{46}$.

Choć każdy z historyków Kościoła opisuje losy Atanazego bardzo dokładnie, jedynie u Sozomena postać Antoniego Pustelnika pojawia się w kontekście wydarzeń, które miały miejsce po śmierci Ariusza. Atanazy przebywał w tym czasie na swoim pierwszym wygnaniu ${ }^{47}$. Sozomen poświęca tej sprawie wiele miejsca, zaznaczając, że za wygnanym biskupem wstawiał się nie tylko Antoni, ale czynił to także lud Aleksandrii. Zgodnie z relacją Sozomena Antoni niejednokrotnie pisał do cesarza w tej sprawie, zaklinając władcę, by nie wierzył melicjanom ${ }^{48}$ i za oszczerstwo uważał ich oskarżenia ${ }^{49}$. Sozomen nie przytacza więc pełnej treści listu, ale wspomina krótko, jaka była jego zawartość. Dość dokładnie przedstawia za to odpowiedź cesarza udzieloną Antoniemu ${ }^{50}$. List Antoniego nie odniósł jednak zamierzonego skutku, a Atanazy mógł wrócić do Egiptu dopiero po roku 337, kiedy zmarł cesarz Konstantyn ${ }^{51}$.

Antoni utrzymywał kontakty nie tylko z władcami i biskupami. W Historiach Kościoła znajdziemy również informacje o jego relacjach z innymi mnichami. Sokrates Scholastyk wspominał w tym kontekście tylko o Dydymie Ślepym ${ }^{52}$ i Ammunie. Sozomen informuje także o spotkaniach Antoniego z Hilarionem, Pawłem

\footnotetext{
${ }_{45}$ Teodoret, Historia Kościoła, IV, 14, [w:] P. Schaff, Nicene and Post-Nicene Fathers, Ser. 2, t. 3, New York 1892 (dalej: TeOdoret, $H E$ ).

${ }^{46}$ Sozomen, HE II, 17.

${ }^{47} \mathrm{Z}$ urzędu złożył go w roku 335 synod w Tyrze. Powodem odwołania były zarzuty, jakie mu stawiali jego przeciwnicy: łapówki, nielegalny podatek od lnu, zatrudnianie ludzi, którzy mieli zastraszać jego przeciwników.

${ }^{48}$ Melicjanami nazywa się zwolenników biskupa Melicjusza z Likopolis, który był zaciekłym przeciwnikiem powrotu do wspólnoty kościelnej osób, które wyrzekły się wiary chrześcijańskiej w czasie prześladowań. Melicjanie wysuwali wiele oskarżeń wobec Atanazego - m.in. w roku 331 i 334. Oskarżyli go m.in. o zamordowanie biskupa Arseniusza, co okazało się nieprawdą.

49 Sozomen, HE II, 31.

${ }^{50}$ W sprawie wymiany listów pomiędzy Antonim a cesarzem por. wyżej.

${ }^{51}$ F. Drączkowski, Patrologia, Lublin 1998, s. 85

${ }^{52}$ Dydym Ślepy, nazywany również Aleksandryjskim, urodził się w roku 313, a zmarł w 398. W wieku czterech lat miał utracić wzrok, ale pomimo swojej ułomności zdobył wykształcenie i został kierownikiem Aleksandryjskiej Szkoły Katechetycznej (nominował go na to stanowisko Atanazy).
} 
Prostakiem i Stefanem. Najwięcej informacji mamy na temat kontaktów Antoniego z Dydymen Ślepym ${ }^{53}$. Sozomen przytacza słowa pochwały, jakie pustelnik skierował do Dydyma. Antoni zgodnie z relacją Sozomena miał powiedzieć:

Nieprzykra bynajmniej to sprawa i niewarta smutku, o, Dydymie, że brak ci oczu, które przypadły w udziale jaszczurkom czy myszom i lichym zwierzętom. Szczęsna natomiast i ponętna to rzecz, że podobnie jak i aniołowie masz oczy, którymi przenikliwie spoglądasz na to, co należy do Boga, i posiadasz dokładne rozeznanie, czym jest wiedza prawdziwa ${ }^{54}$.

\section{Relację na temat tego spotkania przekazuje także Sokrates:}

Podobno i Antoni jeszcze przed okresem rządów Walensa, kiedy to z powodu arian opuścił swą pustelnię i przybył do Aleksandrii, spotkał się z Dydymem i zorientowawszy się w głębokiej mądrości tego męża, powiedział do niego: „Nie martw się Dydymie, że utraciłeś oczy cielesne. Nie masz bowiem takich oczu, jakimi mogą patrzeć i muchy, i komary; ciesz się natomiast, że masz oczy, którymi patrzą także i aniołowie, oczy, za pośrednictwem których również i sam Bóg jest oglądany i dostrzegana jest Jego światłość". To powiedział już dawniej do Dydyma umiłowany przez Boga Antoni ${ }^{55}$.

Podobieństwo pomiędzy obydwoma tekstami wyjaśnić jest bardzo łatwo. Sozomen korzystał z dzieła Sokratesa. Obydwaj mogli również zasięgnąć informacji o tym spotkaniu z innych źródeł ${ }^{56}$. Wiemy jednak, że spotkania Dydyma i Antoniego miały miejsce więcej niż raz. Informuje o tym Palladiusz, wspominając o trzeciej wizycie Antoniego u Dydyma - wiadomość ta jest o tyle prawdopodobna, że zgodnie z relacją Palladiusza przekazał mu ją sam Dydym ${ }^{57}$. Nie wiemy nie-

${ }^{53}$ O Dydymie Ślepym, por. B. CzyżEwsкi, Dydym Aleksandryjski - Ojciec zapomniany, „Studia Gnesnensia", t. 11 (1997), s. 305-312; B. J. HuculaK, Wczesnochrześcijańska nauka o Duchu Świętym w przekazie Dydyma Aleksandryjskiego nazywanego Ślepcem, „Roczniki Teologiczne”, z. 2 (2003) s. 101-116; D. SzymańsKa-Kuta, Dydym Ślepy: mistrz szkoły aleksandryjskiej (przegląd źródeł), „Zeszyty Naukowe Uniwersytetu Jagiellońskiego. Studia Religiologica” 2010, s. 77-92; R. NAKONIECZNY, Teologia kreacji - między obrazem a podobieństwem (na podstawie „In Genesin” Dydyma Aleksandryjskiego), „Vox Patrum” 48 (2005), s. 105-123; R. A. Layton, Didymus the Blind and His Circle in Late-Antique Alexandria, Chicago 2004; R. Nakonieczny, Znaczenie terminu tò $\pi v \varepsilon \tilde{u} \mu \alpha$ w antropologii Dydyma Aleksandryjskiego, „Vox Patrum” 49 (2006), s. 445-452; B. CzyżEwski, Obraz Kościoła w „Komentarzu do Zachariasza” Dydyma Aleksandryjskiego, „Vox Patrum” 52 (2008), s. 109-122; B. Czyżewski, Chrystologia w „Komentarzu do Zachariasza” Dydyma Ślepego, Gniezno 1996; R. M. PAncerz, Jeszcze o duszy Chrystusa wedlug Dydyma Ślepego, „Vox Patrum” 52 (2008), s. 827-841; R. M. Pancerz, Zarys doktryny Dydyma Ślepego o duszy Chrystusa, „Przegląd Kalwaryjski" 14 (2010), s. 77-88.

${ }^{54}$ Sozomen, HE III, 15.

${ }_{55}$ O Dydymie Ślepym krótko informuje również Teodoret z Cyru, HE IV, 26.

56 D. Szymańska-Kuta, Dydym Ślepy - mistrz szkoły aleksandryjskiej (przegląd źródeł), „Zeszyty Naukowe Uniwersytetu Jagiellońskiego", 43 (2010), s. 77-79.

${ }^{57}$ HL IV, 3. 
stety, kiedy miało miejsce opisane spotkanie. Podana w tekście Sokratesa informacja, że miało ono miejsce przed okresem rządów Walensa, niewiele nam pomoże - Walens rozpoczął swoje panowanie w roku 364, ale Antoni zmarł w roku 356. Drugą wskazówką chronologiczną jest sprawa arian - Sokrates twierdzi, że Antoni przybył do Aleksandrii z ich powodu, a Sozomen dodaje, że chodziło o zaświadczenie o prawowierności Atanazego. Wydarzenie to miało miejsce w roku $338^{58}$. Jeśli przyjmiemy, że spotkanie opisywane przez historyków Kościoła było pierwszym, to do wszystkich spotkań, minimum trzech, musiałoby dojść pomiędzy rokiem 338 a 356.

Kolejnym ascetą, który miał spędzić wiele czasu z Antonim, był Paweł Prostak, będący jego uczniem. Jeśli chodzi o Historie Kościoła, wspomina o tej postaci jedynie Sozomen. Jego informacje porównać można z tym, co przekazują Opowiadania dla Lausosa, Historia Mnichów w Egipcie i Apoftegmaty ${ }^{59}$. Zgodnie $\mathrm{z}$ relacją Sozomena Paweł był z pochodzenia wieśniakiem. Ożenił się z kobietą niezwykłej urody, którą przyłapał na cudzołóstwie. Porzuciwszy małżonkę i dom, udał się na pustynię do Antoniego Pustelnika, ponieważ pragnął zostać mnichem. Wszystkie źródła zgodne są co do tego, że Paweł został uczniem Antoniego Pustelnika. Apoftegmaty jedynie wspominają ten fakt ${ }^{60}$, natomiast pozostałe przekazy dokładnie opisują drogę, jaką musiał przejść Paweł. Najkrótsza informacja na ten temat znajduje się u Sozomena: Antoni poddał Pawła rozmaitym próbom, z których ten wyszedł zwycięsko mimo swojego podeszłego wieku. Choć Sozomen nie precyzuje, jakiego rodzaju były to próby, to łatwo wywnioskować, że chodzi o ćwiczenia ascetyczne, jakie zazwyczaj towarzyszą życiu mnichów. Szczegółów dowiadujemy się z Opowiadań dla Lausosa ${ }^{61}$ i Historii mnichów w Egipcie ${ }^{62}$. Palladiusz relacjonuje, że Antoni początkowo nie chciał przyjąć Pawła, uważając, iż ten jest za stary jak na kogoś, kto pragnie rozpocząć życie monastyczne ${ }^{63}$. Próby, którym początkowo poddał Pawła, miały go do tego zniechęcić. Dopiero po upływie pewnego czasu, kiedy Antoni przekonał się o wytrzymałości i posłuszeństwie Pawła, próby te nabrały charakteru pewnego rodzaju nowicjatu. Według narracji Palladiusza i Historii Mnichów w Egipcie wszelkie próby, którym został poddany

\footnotetext{
${ }^{58}$ W. Harmless, op. cit., s. 71.

${ }^{59}$ Każde z tych źródeł, z wyjątkiem Apoftegmatów, prowadzi swoją relację o życiu Pawła w podobnym porządku chronologicznym - zaczynając od wydarzeń jeszcze sprzed zostania mnichem, aż do opuszczenia siedziby Antoniego i rozpoczęcia samotnej ascezy. Apoftegmaty skupiają się na tym, co działo się z Pawłem, kiedy był już szanowanym i doświadczonym mnichem.

${ }^{60}$ AP 797

${ }^{61}$ HL XXII, 4-8.

${ }^{62}$ HM XXIV, 2-9; 31, 4-13.

${ }^{63}$ Antoni miał nawet zamknąć się w swojej pustelni i nie wychodzić przez trzy dni, w nadziei, że Paweł zniechęci się i odejdzie. Grecka wersja Historii mnichów w Egipcie twierdzi, że Antoni nie wychodził aż przez tydzień, natomiast łacińska, iż tylko jeden dzień i noc. Sozomen całkowicie pomija tę kwestię.
} 
Paweł, miały go nauczyć przede wszystkim posłuszeństwa ${ }^{64}$. Sozomen tymczasem w ogóle nie dotyka tej tak ważnej dla historii Pawła sprawy. Nie jest raczej możliwe, że nie słyszał o tej stronie nauki Pawła (Sozomen znał chociażby Historię Mnichów $w$ Egipcie). Raczej świadomie ominął tę część opowieści, jego relacja o Pawle jest bowiem bardzo krótka. Znajduje się w niej jednak pewien zwrot, który być może odnosi się do kwestii posłuszeństwa, którego Antoni uczył Pawła. Sozomen wspomina, że Paweł był nieprzyzwyczajony do „mniszej pokory”65. Żadne ze źródeł nie podaje, jak długo Paweł pozostawał w pustelni Antoniego. Jedynie Palladiusz sugeruje, że nauka Pawła trwała kilka miesięcy ${ }^{66}$. Po tym czasie Paweł zamieszkał samotnie, zgodnie z relacją Sozomena Antoni polecił mu, by „sam sobie był mistrzem"67. Palladiusz informuje, że pustelnia Pawła znajdowała się w odległości trzech lub czterech mil od miejsca zamieszkania Antoniego ${ }^{68}$. Po roku spędzonym w tym miejscu Paweł uzyskał umiejętność wyganiania demonów. Co bardzo ciekawe, miał być w tym lepszy niż sam Antoni ${ }^{69}$.

Życie św. Antoniego było przykładem dla wielu nie tylko w Egipcie, ale i w innych stronach chrześcijańskiego świata. Jego kult rychło rozprzestrzenił się na całym Wschodzie. Choć Historie Kościoła nie są głównym źródłem do poznania dziejów Antoniego, przekazują bardzo wiele informacji na jego temat. Wyłania się z nich obraz człowieka niezwykłego, obdarzonego wielkim autorytetem wśród ówczesnego społeczeństwa. Późniejsza tradycja nazwała Antoniego pierwszym mnichem - prekursorem tego rodzaju życia. Choć obecnie rola Antoniego jako twórcy monastycyzmu nie jest już powszechnie uznawana, to nadal uważa się, że jego udział w tworzeniu podwalin pod ideę życia monastycznego był znaczący. Nie możemy jednoznacznie stwierdzić, czy obraz Antoniego, który przedstawiają Historie Kościoła, odpowiada całkowicie rzeczywistości. Historycy za główne źródło mieli dzieło Atanazego, które w założeniu miało wychwalać działalność pustelnika. Historycy Kościoła mieli także własne poglądy na środowisko mnichów - widzieli w nich świętych mężów, do których zadań należało nauczanie, nieraz nawracanie pogan, dawanie dobrego przykładu swoim życiem, a także czynienie cudów, które były dowodem Bożej łaski. Postać Antoniego przedstawiona w Historiach Kościoła w pełni wpisuje się właśnie w taki wizerunek mnicha.

\footnotetext{
${ }^{64}$ Nakaz nabierania wody ze studni, a potem jej wylewania (HM XXXI, 13); plecenie koszyków i rozplatanie dopiero co zrobionych (HM XXXI, 13); nakaz splatania i rozplatania liny (Palladiusz, XXII, 5); zszywanie i rozdzieranie niedawno zszytej odzieży (HM XXXI, 13); nakaz rozbicia naczynia z miodem i zebrania zawartości łyżeczką (HM XXIV, 8); nakaz milczenia (HM XXIV, 6-7; HM XXXI, 9-11) i długotrwałych postów (HM XXIV, 2)

${ }^{65}$ Sozomen, HE I, 13.

${ }^{66}$ HL XXII, 9.

${ }^{67}$ Sozomen, HE I, 13

${ }^{68}$ HL XXII, 9

${ }^{69}$ Sozomen, HE I, 13, HL, 9-10, HM XXXI, 18; HM XXIV, 10.
} 